\title{
Relationship between sea surface temperature and the nesting of the Olive Ridley sea turtle Lepidochelys olivacea (Testudines: Cheloniidae) in Gorgona Island, Colombian Pacific
}

\author{
María Alejandra Ariza Gallego ${ }^{1 *}$, Julio César Herrera Carmona ${ }^{2}$, Luis Fernando Payán ${ }^{3}$ \\ \& Alan Giraldo ${ }^{1,2}$ \\ 1. Universidad del Valle, Facultad de Ciencias Naturales y Exactas, Departamento de Biología, Grupo de Investigación \\ en Ecología Animal, Postal code 760032057, Cali, Colombia; maria.ariza@correounivalle.edu.co, \\ alan.giraldo@correounivalle.edu.co \\ 2. Universidad del Valle, Facultad de Ciencias Naturales y Exactas, Departamento de Biología, Grupo de Investigación \\ en Ciencias Oceanográficas, Postal code 760032057, Cali, Colombia; juliocesar.herreracarmona@gmail.com \\ 3. Estación Científica Henry von Prahl, Parque Nacional Natural Gorgona, Territorial Pacífico, Parques Nacionales \\ Naturales de Colombia, Gorgona, Colombia; estacioncientificagorgona@gmail.com \\ * Correspondence
}

Received 05-VIII-2019. Corrected 08-I-2020. Accepted 10-III-2020.

\begin{abstract}
Introduction: Lepidochelys olivacea is the most abundant sea turtle in the Colombian Pacific and oceanographic conditions at the Eastern Tropical Pacific may have an effect on its reproductive behavior Objective: To assess the relationship between reproductive aspects of L. olivacea nesting at Gorgona island and sea surface temperature at local and regional scales. Methods: Monthly mean data of reproductive attributes associated with nesting females, nests, eggs and hatchlings were established using records from Gorgona's National Natural Park nesting monitoring and were correlated (cross-correlations) with SST of Gorgona island and Panama Bight, and with the temperature variability of the El Niño 1+2, El Niño 3, El Niño 3.4 and El Niño 4 regions, their thermal anomalies, and the ONI and SOI indexes. Significant correlations were included in a Generalized Additive Model. Results: Highest inverse correlation since maximum correlation is 1 was established between visits to the beach, number of nesting females, number of nests, clutch size, incubation days and hatching success and Niño 1+2 region with a lag of 12 months, whereas egg diameter, egg weight, straight carapace length and width and weight of hatchlings were correlated with Niño 4 anomaly, SOI and ONI indexes. It was also found that there is a non-linear tendency to decrease number of nesting females, number of nests, clutch size, egg diameter and egg weight with regional positive anomalies. Conclusions: Nesting attributes of $L$. olivacea in Gorgona correlate mainly with variations in regional SST, being low at high sea surface temperatures the year prior to nesting (12-month lag).
\end{abstract}

Key words: ENSO indexes, thermal anomaly, Eastern Tropical Pacific, Colombia, conservation.

Ariza Gallego, M.A., Herrera Carmona, J.C., Payán, L.F., \& Giraldo, A. (2020). Relationship between sea surface temperature and the nesting of the Olive Ridley sea turtle Lepidochelys olivacea (Testudines: Cheloniidae) in Gorgona Island, Colombian Pacific. Revista de Biología Tropical, 68(2), 528-540.

The Eastern Tropical Pacific (ETP) is a region that has unique oceanographic and environmental conditions for planktonic and higher trophic level organisms that inhabit it (Chavez et al., 1999; Lavín et al., 2006). This region extends from the Southwestern coast of Baja California to northern Peru and has a strong variability that operates at different scales of space and time in the conditions that characterize it (Amador, Alfaro, Lizano, \& Magaña, 
2006; Fiedler \& Lavín, 2016), such as the interannual variability generated by El NiñoSouthern Oscillation (ENSO) event which is probably one of the oceanic-atmospheric processes that has the highest incidence in the ETP, both in its warm phase (El Niño), and in its cold phase (La Niña) (Montealegre, 2007; Fiedler \& Lavín, 2016).

One of the most outstanding aspects of ENSO is the unusual variations in the sea surface temperature (SST) (Wang \& Fiedler, 2006) since this oceanographic parameter significantly affects the atmosphere and also generates a physiological, ethological and ecological response in marine organisms (O'Connor et al., 2007; Côté \& Green, 2015; Gunderson, Armstrong, \& Stillman, 2016). The effects of the SST variation caused by ENSO on marine organisms have been historically focused on establishing their relationship with the dynamics of primary consumers and planktonic producers such as phytoplankton, copepods or larvae of commercial interest organisms such as fish larvae, squid and crustaceans (Paredes, Cardoso, \& Tarazona, 2004; Masotti et al., 2011; Kozak, Franco-Gordo, Suárez-Morales, \& Palomares-García, 2014; León-Chávez, Beier, Sánchez-Velasco, Barton, \& Godínez, 2015; Alabia et al., 2016). However, these taxonomic groups directly affect the survival, reproduction, and distribution of higher trophic level organisms like mammals, sea birds, and sea turtles (Ballance, Pitman, \& Fiedler, 2006; Polidoro et al., 2012).

The ETP is also one of the most important regions for marine turtles Hawksbill (Eretmochelys imbricata), Leatherback (Dermochelys coriacea), Green (Chelonia mydas), Loggerhead (Caretta caretta) and Olive Ridley (Lepidochelys olivacea), since it shelters extensive nesting beaches and feeding sites, where these species have access to a diversity of marine habitats such as sea grass pastures, mangrove estuaries, open waters and coral and rocky reefs (Seminoff et al., 2012). According to Pritchard and Plotkin (1995), throughout Central America, warming due to El Niño conditions could be partially responsible for declines in the number of nesting females of Lepidochelys olivacea. In this species, changes have also been reported in their post-nesting migratory routes in response to the El Niño effect (Plotkin, 2010).

L. olivacea is considered the most abundant sea turtle in the world, despite being listed as a vulnerable species according to the red list of the International Union for the Conservation of Nature-IUCN (IUCN, 2019). In addition to the ETP, this species is distributed in tropical waters of the Indian and South Atlantic Ocean basins (Barrientos-Muñoz, Ramírez-Gallego, \& Páez, 2015). In Colombia, it is the most common nesting turtle of the Pacific (Amorocho, Rodríguez-Zuluaga, Payán, Zapata, \& Rojas, 2015), despite this, studies on its reproductive biology in Colombia have been reduced, spaced in time and carried out in a few locations (Amorocho, Rubio, \& Díaz, 1992; McCormick, 1996; Martinez \& Páez, 2000; Hinestroza \& Páez, 2001; Pavía, Rodríguez-Zuluaga, \& Amorocho, 2006; Barrientos-Muñoz \& Ramírez-Gallego, 2008; Barrientos-Muñoz, Ramírez-Gallego, \& Páez, 2014; Payán-Perea, Zorrilla-Arroyave, \& Chirimía-Gonzáles, 2016). In this context, it is relevant to evaluate the effect that thermal variations associated with ENSO could have on marine turtle species of the Colombian Pacific, particularly on the different attributes related to the nesting process of L. olivacea in the marine protected area of Gorgona island.

For this purpose, the historical record of the "Marine Turtle Monitoring Program of Gorgona National Natural Park (PNNG)" was used to consolidate the monthly information related to females, nests, eggs and hatchlings of L. olivacea between 2008 and 2018 in Playa Palmeras. This information was correlated with SST of Gorgona island and Panama Bight, and with the indexes of El Niño 1+2, El Niño 3, El Niño 3.4 and El Niño 4 regions, their thermal anomalies, and the ONI and SOI indexes, with the objective of evaluating the effect of the SST on nesting attributes of L. olivacea in Playa Palmeras, Gorgona island, considering the oceanic variability both on a local and regional scale. 


\section{MATERIALS AND METHODS}

Study area: Gorgona Island $\left(2^{\circ} 55^{\prime} 45^{\prime \prime}\right.$ - $3^{\circ} 00^{\prime} 55^{\prime \prime} \mathrm{N} \& 7^{\circ} 09^{\prime}$ - 78 $78^{\circ} 14^{\prime} 30^{\prime \prime} \mathrm{W}$ ) is located in the south of the Colombian Pacific, $30 \mathrm{~km}$ from the coast of Cauca and Nariño departments. It is $9 \mathrm{~km}$ long and $2.5 \mathrm{~km}$ wide (Giraldo, Rodríguez-Rubio, \& Zapata, 2008; Amorocho, Rodríguez-Zuluaga, Payán, Zapata, \& Rojas, 2015) and the surface waters remain relatively constant throughout the year, with warm temperatures between 26 and $28.6{ }^{\circ} \mathrm{C}$ (Giraldo, Valencia, Acevedo, \& Rivera, 2012). In 1984, the island and its marine area, were declared Natural National Park, with the aim of preserving species and ecosystems representative of terrestrial and marine flora and fauna of the Pacific. Marine turtles are considered a value object of conservation for the PNNG, reason for which permanent monitoring efforts have been directed since 2008 (Amorocho et al., 2015; Barrientos-Muñoz et al., 2015; Payán-Perea et al., 2016).

In Gorgona Island, sea turtle nesting monitoring is carried out in Playa Palmeras, a sandy beach located at the Southwestern end of the island $\left(2^{\circ} 56^{\prime} 38^{\prime \prime} \mathrm{N}-78^{\circ} 11^{\prime} 53^{\prime}\right.$ " W \& $\left.2^{\circ} 56^{\prime} 19^{\prime \prime} \mathrm{N}-78^{\circ} 12^{\prime} 16^{\prime \prime} \mathrm{W}\right)$. It has a total extension of $1.2 \mathrm{~km}$, being the largest sandy beach on Gorgona. For nesting monitoring, the beach has been divided in six sectors, every 200 meters, numbered from north to south (Payán-Perea et al., 2016).

Data collection: "PNNG Marine Turtle Nesting Monitoring" consists of night patrols between July and November, along Playa Palmeras between 20:00 and 5:00 h if climatic conditions and tides are optimal, in order to intercept nesting turtles and/or search for traces and nests. The staff willing to take data is at least two people per night.

For each turtle found, curved carapace length (CCL) and curved carapace width (CCW) measurements are taken using a tape measure and, straight carapace length (SCL) and straight carapace width (SCW) are taken using a caliper. Subsequently, they are marked with one metal tag in the second scale of the anterior fin, placing the tags marked with an odd number on the left fin and with an even number on the right. After identifying a nest, the eggs are relocated to a hatchery if the nesting site poses a risk of flooding. In each relocated nest, number of eggs is recorded and ten eggs are randomly selected to record the diameter using a caliper and the weight using a $50 \mathrm{~g}$ weight. Forty-five days after nesting, the nests are monitored until the emergence of hatchlings. Once they emerge, they are counted and ten are taken at random to register their weight, straight carapace length, and straight carapace width. Finally, the hatchlings are released in the sand.

A database was consolidated from the record sheets of this monitoring program, establishing monthly information on the number of visits to the beach, defined as any evidence of arrival of a turtle (VB), number of nesting females (NNF), number of nests (NN), clutch size, defined as the number of eggs per nest (CZ), incubation days (ID), hatching success (HS), defined as the percentage of live hatchlings over the $\mathrm{CZ}$, diameter (ED) and weight (EW) of eggs, straight carapace length (SCLh), straight carapace width (SCWh) and weight (Wh) of the hatchlings of L. olivacea, from 2008 to 2018 , for a total of eleven years of monitoring data. The number of nesting females was estimated from the method of Alvarado and Murphy (1999), where the number of nests is divided by the average number of nests per female per year (2.5 for Lepidochelys sp.).

The SST information for Gorgona (GOR) and Panama Bight (PB) (local scale), was obtained from monthly images of level 3 with $4 \mathrm{~km}$ resolution from NASA's MODIS- Aqua sensor (Ocean Biology Processing Group, 2015). For GOR, the SST information was extracted from the CPC16 station of ERFEN grid (Program for the Regional Study of El Niño Phenomenon in the Southeast Pacific) $\left(3^{\circ} 0{ }^{\prime} 0 " \mathrm{~N}-78^{\circ} 0\right.$ ' 0 " $\left.\mathrm{W}\right)$. For $\mathrm{PB}$, information was extracted from a sampling grid of 86 stations distributed in Panama Bight and separated 
by $1^{\circ}$ of latitude and longitude. The extraction of information from the images was carried out through virtual samplings using ArcGIS 10.5.

For regional SST, monthly information was obtained from climatic variability indexes: El Niño Regions 1+2, 3, 3.4 and 4, their thermal anomalies (ANOM 1+2, ANOM 3, ANOM 3.4 and ANOM 4) and the ONI (Oscillation Niño Index) and SOI (Southern Oscillation Index) indexes from the NOAA (National Oceanic and Atmospheric Administration) Climate Prediction Center, ERSSTv5 dataset (Climate Prediction Center Internet Team, 2017).

Monthly and annual descriptive analyzes of nesting variables were carried out and subsequently, monthly time series were constructed with SST information, indexes and anomalies and the nesting attributes of L. olivacea, taking only the nesting records from July to November. With this set of time series, cross correlations were made to evaluate the relationship between nesting variables and climatic variability indexes, both in simultaneous (lag 0), and at a later time. The nesting variables were lagged in 24 months. The lags with the highest correlations were included in Generalized Additive Models (GAM). All analyzes were done with STATISTICA 7.0 (StatSoft, 2004).

\section{RESULTS}

Between 2008 and September of 2018, a total number of $513 \mathrm{~L}$. olivacea arrival records and 486 nests were obtained, for which the NNF was estimated in 194; There were 221 encounters with turtles, of which 169 were females tagged for the first time and 39 were recaptures. The average measurements, in centimeters, of the intercepted females were: CCL $=65.37 \pm 2.44 ; \mathrm{CCW}=69.34 \pm 3.20 ; \mathrm{SCL}$ $=60.83 \pm 2.62$ and $\mathrm{SCW}=54.34 \pm 3.02$. Fig. 1 shows the average monthly records of $\mathrm{VB}, \mathrm{NNF}$ and NN, where it is identified that September (month 9), was the month in which the highest average of records was obtained for this three variables $(\mathrm{NN}=17.72 \pm 6.26, \mathrm{VB}=$ $17.09 \pm 8.89, \mathrm{NNF}=7.09 \pm 2.50)$.

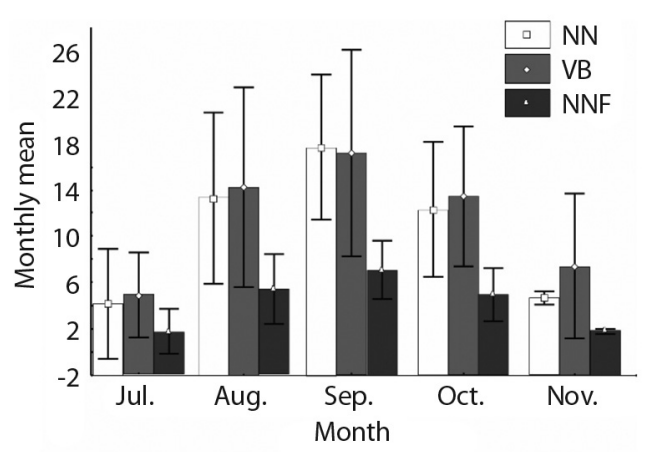

Fig. 1. Monthly nesting records of Lepidochelys olivacea in Playa Palmeras, Gorgona island, during July-November (7-11). Period evaluated: 2008-2018 (11 years). NN = Number of nests/month; NNF = Number of nesting females/month; $\mathrm{VB}=$ Number of visits to the beach $/$ month.

There were 32864 eggs counted corresponding to 347 relocated nests $(71.4 \%$ of total). The average $\mathrm{CZ}$ was $94.71 \pm 19.32$ and average ID was $57.03 \pm 4.60$. The average diameter and weight of 2968 eggs was: ED $=3.75 \pm 0.25 \mathrm{~cm}$ and $\mathrm{EW}=32.91 \pm 3.9 \mathrm{~g}$. Related to hatchlings, there were 17730 births recorded corresponding to 249 nests $(49.17 \%$ of total nests). In these, the total average hatching success was $67.07 \%$.

In the eleven years period, it was possible to identify interannual variations in all the nesting variables. Fig. 2 and Fig. 3 show the monthly averages of the nesting variables in each year. 2010 was year with the lowest averages of HS $(51 \%)$, ED $(3.39 \pm 0.27 \mathrm{~cm})$, $\operatorname{SCLh}(3.74 \pm 0.19 \mathrm{~cm})$ and SCWh $(2.96 \pm 0.21$ $\mathrm{cm}) ; 2008$, the one with the lowest CZ (84.78 \pm $16.89)$ and 2015 , the lowest ID (54.59 \pm 3.99$)$. On the contrary, the years with the highest monthly averages were: 2013 with $\mathrm{ED}=3.91$ $\pm 0.20 \mathrm{~cm}$ and $\mathrm{SCWh}=3.61 \pm 0.24 \mathrm{~cm} ; 2014$ with $\mathrm{HS}=85.73 \%, \mathrm{SCLh}=4.34 \pm 0.19 \mathrm{~cm}$ and $\mathrm{EW}=35.23 \pm 3.97 \mathrm{~g}, 2017$ with $\mathrm{Wh}=20.35$ $\pm 1.02 \mathrm{~g} ; 2012$ the highest CZ $(100.42 \pm 11.08)$ and 2009 the highest ID $(59.88 \pm 5.24)$.

The cross-correlation analysis between the variables of females and nests NN, NHA, VP, TN, DI, EE and climatic indexes El Niño 1+2, 3, 3.4, 4, ONI, ANOM 1+2, ANOM 3, ANOM 3.4 and ANOM 4 and the SST of GOR and PB, 


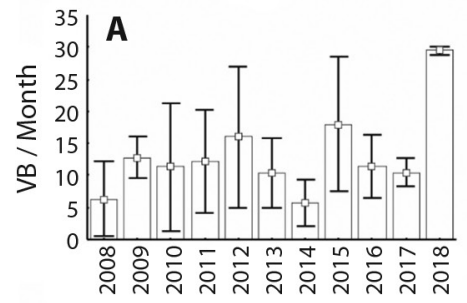

Years

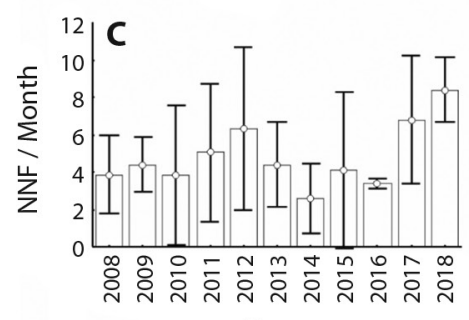

Years

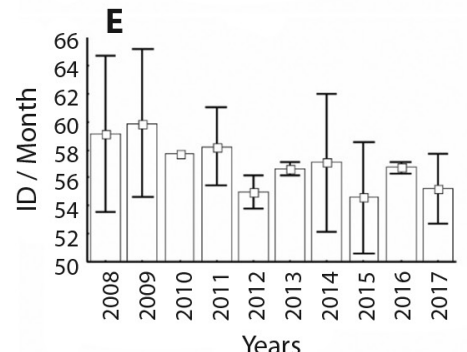

Years

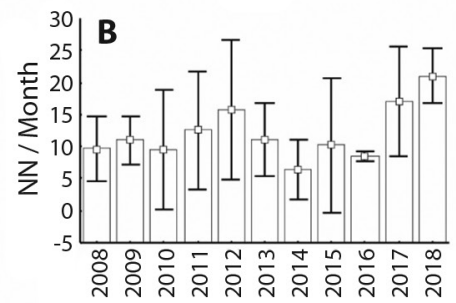

Years

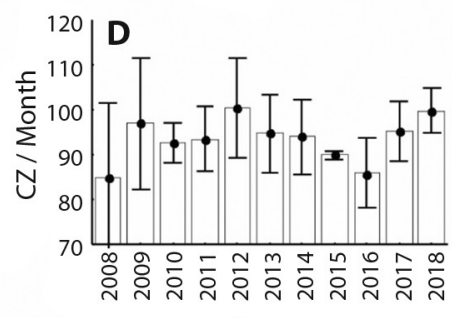

Years

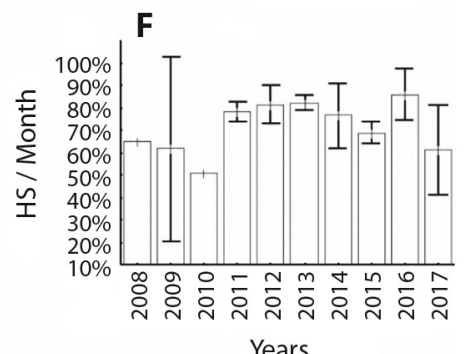

I Mean \pm SD

Fig. 2. Annual nesting records of variables related to females and nests of Lepidochelys olivacea in Playa Palmeras, Gorgona Island. Period evaluated 2008-2018 A. Annual average of visits to the beach per month B. Annual average of nests per month; C. Annual average of nesting females per month D. Annual average of size of nests per month; E. Annual average of incubation days per month; F. Annual average hatching success per month.

indicated significant correlations, of which, the highest correlation since maximum correlation is 1 , were negative. That is, when the SST decreased locally and regionally and there were negative anomalies, high values of the nesting variables were found. In the case of SOI, when it was in its positive phase, there was also an increase in the nesting variables. The Niño $1+2$ index presented the highest significant negative correlations for these variables, with a 12-month lag, followed by the GOR SST, in which the highest significant lag was 8-9 months. However, high positive significant correlations were also identified in lags 0 and 6 with Niño $1+2$. For all cases, with these variables, the lag of highest correlation was equal to or less than 12 months.

For the morphometric variables of eggs and hatchlings, the EW and SCWh had highest negative correlations with all the indexes and SST, except with SOI. For the Wh the correlations were positive and negative with the SOI. The ED had negative correlations, except with Niño 3.4 and finally, with the SCLh both positive and negative correlations were obtained. The greatest lag with these variables was 19 months and the highest correlations were obtained with regional indexes. Fig. 4 shows the values of the highest significant correlations obtained in the cross-correlation tests 

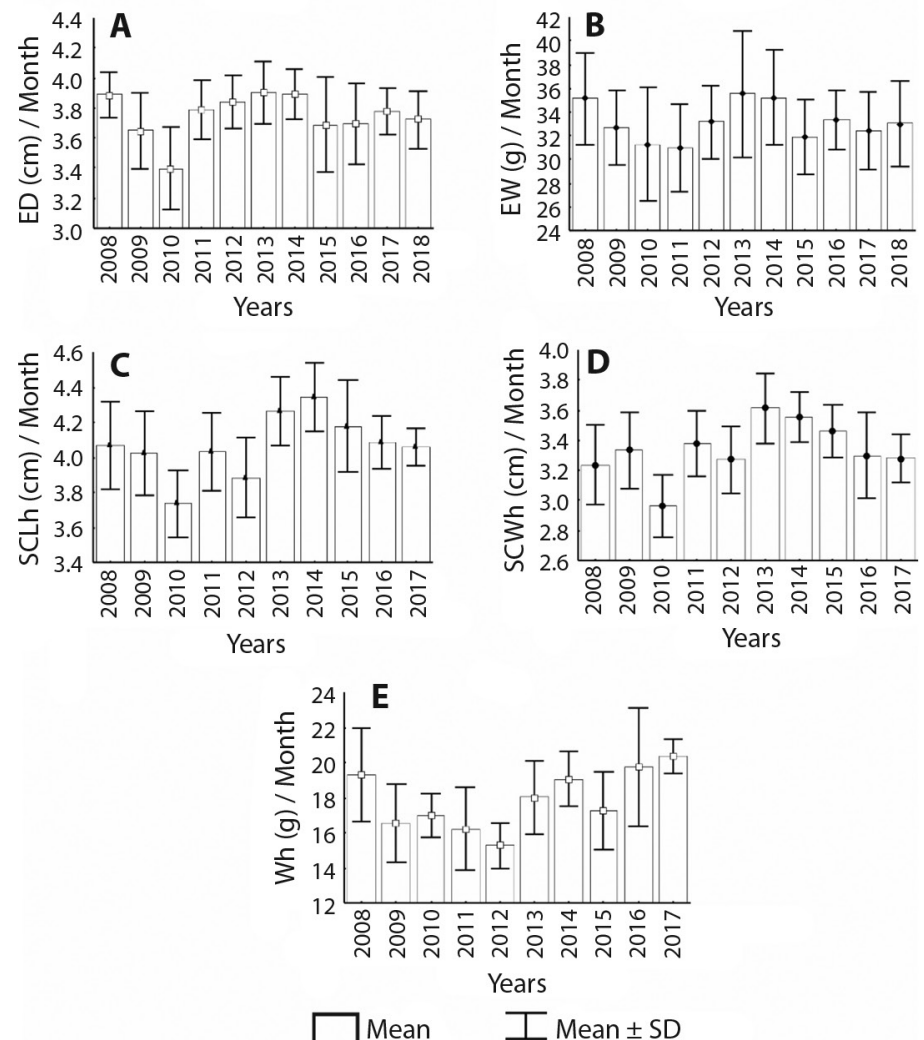

Fig. 3. Annual nesting records of variables related to eggs and hatchlings of Lepidochelys olivacea in Playa Palmeras, Gorgona Island. A. Annual average of egg diameter; B. Annual average of egg weight; C. Annual average of straight carapace length of hatchlings; D. Annual average of straight carapace width of hatclings; E. Annual average weight of hatchlings.

\begin{tabular}{|c|c|c|c|c|c|c|c|c|c|c|c|c|c|c|c|c|c|c|c|c|c|c|}
\hline $\begin{array}{l}\text { SST and } \\
\text { Indexes }\end{array}$ & NN L & Lag & VB & Lag & NNF & Lag & $C Z$ & Lag & ID & Lag & HS & Lag & ED & Lag & EW & Lag & SCLh & Lag & SCWh & Lag & Wh & Lag \\
\hline GOR & $-0,51$ & 8 & $-0,49$ & 8 & $-0,51$ & 8 & $-0,58$ & 9 & $-0,47$ & 9 & $-0,46$ & 8 & $-0,24$ & 10 & $-0,22$ & 3 & $-0,24$ & 7 & $-0,25$ & 7 & 0,28 & 8 \\
\hline PB & $-0,48$ & 10 & $-0,45$ & 10 & $-0,48$ & 10 & $-0,55$ & 10 & $-0,49$ & 10 & $-0,45$ & 10 & $-0,28$ & 9 & $-0,22$ & 3 & $-0,23$ & 7 & $-0,38$ & 8 & 0,36 & 8 \\
\hline Niño 1+2 & $-0,60$ & 12 & $-0,59$ & 12 & $-0,60$ & 12 & $-0,67$ & 12 & $-0,56$ & 12 & $-0,56$ & 12 & & & $-0,19$ & 5 & & & $-0,28$ & 9 & 0,24 & 11 \\
\hline Anom. 1+2 & $-0,25$ & 10 & $-0,25$ & 9 & $-0,25$ & 10 & $-0,29$ & 9 & $-0,21$ & 10 & $-0,21$ & 10 & $-0,28$ & 12 & $-0,30$ & 2 & $-0,25$ & 17 & $-0,28$ & 9 & 0,52 & 7 \\
\hline Niño 3 & $-0,51$ & 11 & $-0,48$ & 11 & $-0,51$ & 11 & $-0,55$ & 11 & $-0,49$ & 11 & $-0,47$ & 11 & 0,23 & 1 & $-0,25$ & 19 & 0,23 & 0 & $-0,41$ & 9 & 0,35 & 11 \\
\hline Anom. 3 & $-0,23$ & 8 & $-0,19$ & 8 & $-0,23$ & 8 & $-0,24$ & 8 & $-0,22$ & 8 & & & $-0,35$ & 12 & $-0,26$ & 19 & $-0,24$ & 10 & $-0,43$ & 8 & 0,49 & 18 \\
\hline Niño 3.4 & $-0,40$ & 8 & $-0,33$ & 8 & $-0,40$ & 8 & $-0,41$ & 9 & $-0,41$ & 9 & $-0,34$ & 8 & 0,30 & 1 & $-0,26$ & 18 & 0,32 & 0 & $-0,48$ & 7 & 0,45 & 0 \\
\hline Anom. 3.4 & $-0,39$ & 8 & 0,33 & 4 & $-0,39$ & 8 & $-0,39$ & 9 & $-0,40$ & 9 & 0,34 & 4 & $-0,28$ & 12 & $-0,25$ & 18 & 0,31 & 0 & $-0,47$ & 7 & 0,44 & 18 \\
\hline ONI & $-0,18$ & 9 & & & $-0,18$ & 9 & $-0,18$ & 8 & $-0,23$ & 9 & $-0,19$ & 12 & $-0,37$ & 11 & $-0,27$ & 20 & 0,34 & 0 & $-0,47$ & 7 & 0,51 & 15 \\
\hline Niño 4 & $-0,40$ & 7 & $-0,33$ & 7 & $-0,40$ & 7 & $-0,40$ & 7 & $-0,42$ & 8 & $-0,34$ & 7 & $-0,36$ & 12 & $-0,27$ & 16 & 0,35 & 1 & $-0,52$ & 6 & 0,50 & 13 \\
\hline Anom. 4 & $-0,23$ & 8 & & & $-0,23$ & 8 & $-0,22$ & 8 & $-0,28$ & 9 & $-0,22$ & 11 & $-0,38$ & 12 & $-0,28$ & 18 & 0,44 & 0 & $-0,52$ & 7 & 0,54 & 13 \\
\hline SOI & 0,21 & 9 & 0,18 & 9 & 0,21 & 9 & 0,22 & 10 & 0,32 & 9 & 0,24 & 9 & $-0,37$ & 2 & 0,24 & 24 & $-0,45$ & 0 & 0,55 & 5 & $-0,50$ & 16 \\
\hline
\end{tabular}

Fig. 4. Highest significant correlations obtained between climatic variability indexes and nesting variables of Lepidochelys olivacea at $\alpha=0.05$. 

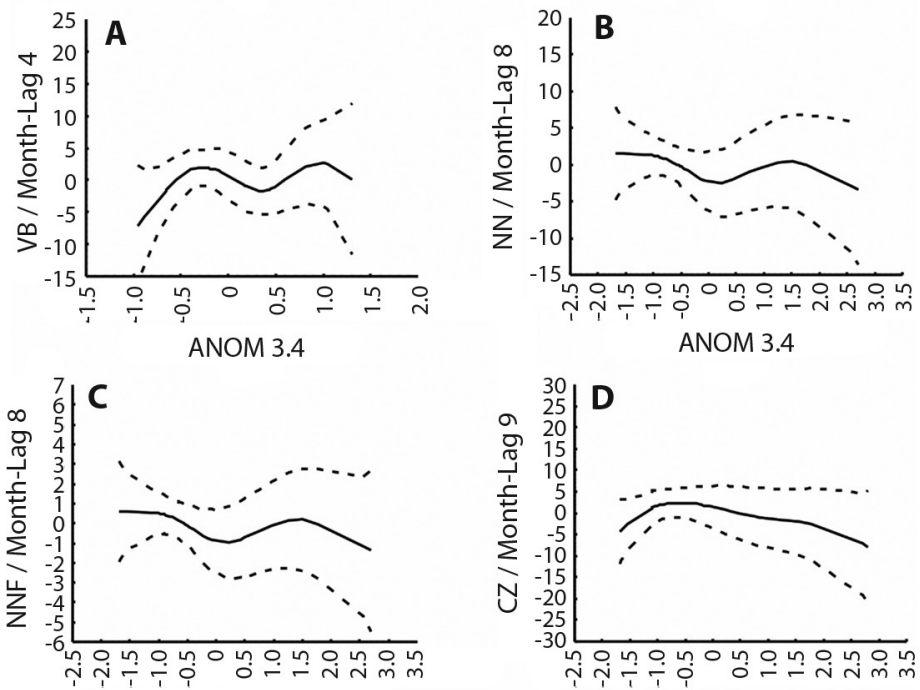

ANOM 3.4

ANOM 3.4

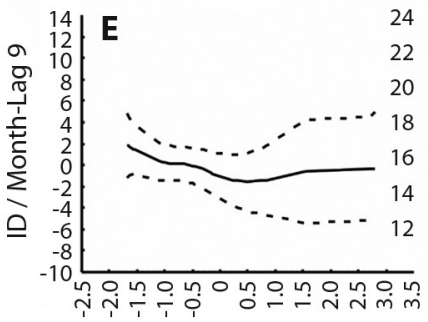

ANOM 3.4

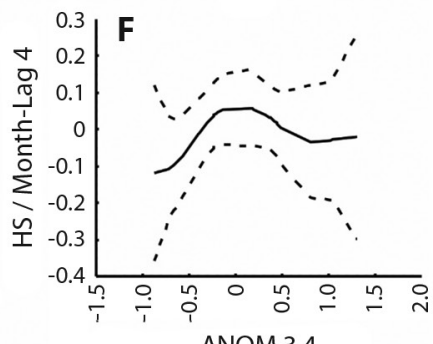

ANOM 3.4

Spline

$95 \%$ conf. band

Fig. 5. Results of Generalized Additive Models (GAM) between lagged variables associated with females and nests of Lepidochelys olivacea and Niño 3.4. anomaly; A. Visits to the beach B. Number of nests; C. Nesting females; D. Clutch size; E. Incubation days; F. Hatching success.

between the pairs of indexes and SSTs and the nesting variables.

Through GAM (Fig. 5, Fig. 6) it was possible to ascertain the non-linearity between the nesting variables and the climatic indices. In the case of VB (Fig. 5A) and HS (Fig. 5F), low values were recorded both at positive and negative extreme values of ANOM 3.4. A slight tendency to reduction was identified in the NN (Fig. 5B), NNF (Fig. 5C) and the CZ (Fig. 5D), with positive values of ANOM 3.4. For ID (Fig. 5E) the trend seemed to be more stable, that is, the positive values of the index do not drastically reduce the ID. Regarding the morphometric variables of the eggs and hatchlings
(Fig. 6), the trend was more pronounced. The tendency to decrease with positive values of the indexes was identified, with the variables ED (Fig. 6A), EW (Fig. 6B), SCLh (Fig. 6C) and SCWh (Fig. 6D). The Wh (Fig. 6E), however, increased with positive values.

\section{DISCUSSION}

The measurements of L. olivacea females found in the PNNG monitoring correspond with those reported on other beaches in the Colombian Pacific (Barrientos-Muñoz \& Ramírez-Gallego, 2008; Hinestroza \& Páez, 2001; Barrientos-Muñoz et al., 2014). Globally, 


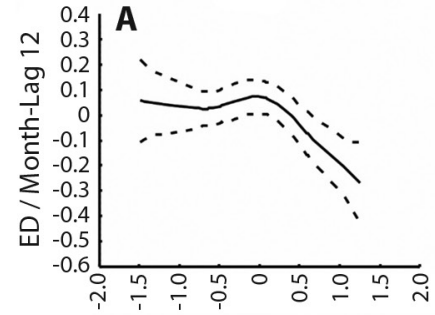

ANOM 4

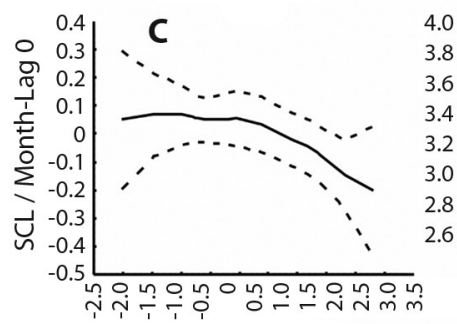

SOI

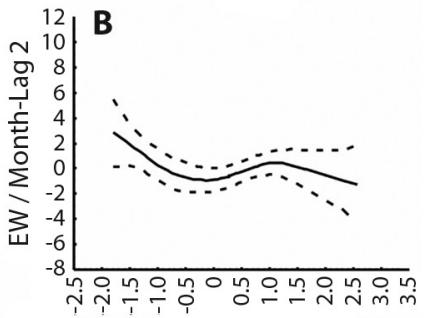

ANOM $1+2$

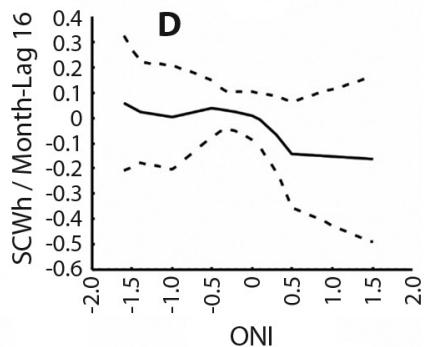

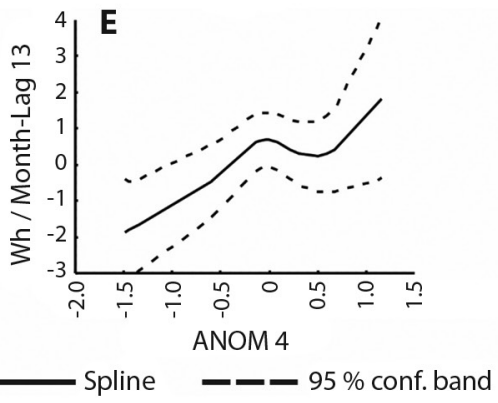

Fig. 6. Generalized Additive Models (GAM) between lagged variables related to eggs and hatchlings of Lepidochelys olivacea and climatic variability indexes. A. Eggs diameter and Niño 4 anomaly; B. Eggs weight and Niño 1+2 anomaly; C. Straight carapace length of hatchlings and SOI index; D. Straight carapace width of hatchlings and ONI; E. Weight of hatchlings and Niño 4 anomaly.

the CCL of the nesting females of L. olivacea varies between 65.9 and $73.1 \mathrm{~cm}$ and those of the populations, between 60.8 and $83 \mathrm{~cm}$, being the smallest marine turtle living species (VaroCruz, Monzón-Argüello, Carrillo, Calabuig, \& Liriz-Loza, 2015). In general, in the Colombian Pacific the nesting season occurs from July to November, with a peak of nesting in september, as well as Gorgona island and there have also been few recaptures considering that this species, unlike others, nests annually and between two and three times per season (Amorocho et al., 1992, 2015; Barreto-Sánchez, 2011; Barrientos-Muñoz et al., 2015).

Regarding the relationship between SST and marine turtles, Mazaris, Kornaraki,
Matsino and Margaritoulis (2004) identified through different models that this variable does represent an important factor for the reproductive behavior of sea turtles, in such a way that sea water temperature is a dynamic stimulus that affects processes associated with reproduction. This relationship has also been reported in C. mydas, (Solow, Bjorndal, \& Bolten, 2002), C. caretta, (Chaloupka, Kamezaki, \& Limpus, 2008; Mazaris, Kallimanis, Sgardelis, \& Pantis, 2008), D. coriacea (Saba et al., 2007, 2008) and E. imbricata (Del Monte-Luna, GuzmánHernández, Cuevas, Arreguín-Sánchez, \& Lluch-Belda, 2012), demonstrating that these effects are independent of the species and the turtle diet. 
Particularly, Chaloupka et al. (2008) using 51-year-old nesting databases, concluded that regardless of whether the populations of $C$. caretta are growing or decreasing the general pattern is that there is an inverse correlation between the SST of the feeding areas and the abundance of the nesting population, even Del Monte-Luna et al. (2012) reproduced the same relationship with E. imbricata on a regional geographic scale. In the present study, this pattern was not only evident in the number of nests and nesting females, but also in the clutches sizes and in the egg diameter and weight of L. olivacea nesting in Playa Palmeras. It should be mentioned that the positive values of SOI, unlike the other indexes and anomalies coincide with abnormally warm waters in the ETP (Climate Prediction Center Internet Team, 2005), so the correlations found with this, correspond to the trend found with the other indexes.

Because of the energy demand experienced by mature females before reproduction that must be greater to carry out vitellogenesis, migration to nesting beaches and the nesting process itself (Hamann, Limpus, \& Whittier, 2002; Wallace, Kilham, Paladino, \& Spotila, 2006), a smaller egg size and weight could be consequence of a lower food availability, accompanied by an increase in the metabolic rate and consequently an accelerated vitellogenesis due to warmer waters in the feeding areas (Wallace \& Jones, 2008). Generally, females require at least one year to store enough fat deposits to carry out this process (Miller, 1997), so the lags that resulted from the highest correlations ( $\leq 12$ months) that were also consistent with the published by Chaloupka et al. (2008) and Mazaris et al. (2008), could reflect the required migration time between feeding and nesting areas.

In this context, possible deficiencies in nutrition, caused by decreases in food availability during 2009-2010 El Niño event, could have caused the low egg sizes recorded in Playa Palmeras (Gorgona island, Colombia) in 2010. This event not only was characterized by strong SST anomalies in the Central Pacific, but also was the event with the fastest transition from El Niño to La Niña registered until then (Kim, Yeh, Kim, Kug, \& Kwon, 2011). However, the abnormally cold temperatures that occurred in 2010, did not produce the largest eggs nor the highest records in the other nesting variables in the following year.

Attributes such as nest size and number of nests are affected by a variety of factors, such as the size and physiological condition of the nesting female, and environmental constraints in nesting and feeding habitats (Miller, 1997). In this sense, the SST could be associated with these variables, however, others such as the hatching success, the incubation days and the physical state of the hatchlings, can change enormously depending on the beach, the sand type, the predation, the tidal regime, rains, sun exposure, etc. (Del Monte-Luna et al., 2012; Varo-Cruz et al., 2015) and probably, for this reason, the trend observed in this study with these variables were not marked and in some cases, contradictory. Additionally, it is very likely that longer time series of nesting records will be needed to establish this type of relationship.

The highest correlations for the variables related to females and nests were presented with the Niño $1+2$ region, with a lag of twelve months. That is, the nesting season attributes would be related to the temperatures that occur in September of the previous year. However, high positive correlations were also found with this index, in other lags. This could be explained by the fact that in this zone there are high seasonal amplitudes in the $\operatorname{SST}\left( \pm>3{ }^{\circ} \mathrm{C}\right)$ and marked seasonal and interannual variations (Fiedler \& Lavín, 2016) so that individuals who remain in colder than optimal conditions could increase their reproductive output as the temperature increases, and those in optimal conditions may experience a decrease as the temperature increases (Mazaris et al., 2008). Another explanation would be that the variables studied would be determined by many factors and the SST is only one of them.

In general, nesting variables had higher correlations with regional SSTs, which 
is consistent with that reported by Del MonteLuna et al. (2012) for Hawksbill turtles in the Atlantic. On the other hand, warmer temperatures in the SST of local waters would be more related to earlier beginnings of nesting seasons, which was not evaluated in this investigation. In addition to this, large-scale indexes tend to be better predictors of ecological processes than local variables (Hallett et al., 2004).

Moreover, through satellite telemetry, Chambault et al., (2016) studied the foraging habits of $L$. olivacea and documented that this species prefers to feed in cold waters, above or below the thermocline, in such a way that the deeper the thermocline is, olive ridleys must invest a greater amount of time and energy in submerging, so they could benefit from the cooler waters and the more shallow thermocline that occur in the Niño $1+2$ region (Fiedler \& Lavín, 2016) and the results obtained would suggest that they would be using this region, or part of it, as an important feeding area, so drastic changes in the SST and therefore in the thermocline of Niño $1+2$ region, would be influencing the preparation prior to reproduction and nesting.

It has also been documented that seabirds that feed in this area (coast of Peru), experience reproductive failures and mortality during El Niño events due to food shortages, unlike those that feed in warmer areas of ETP, which are not severely affected (Ballance et al., 2006). It should be noted that the species and communities that inhabit the ETP have evolved to persist through the almost regular perturbations imposed by the ENSO events (Wang \& Fiedler, 2006) and according to Paine, Tegner and Johnson (1998) this type of disturbances, when occurring in a typical range, do not cause major changes in species in the long-term, regardless how large and infrequent they turn out to be.

However, under the current climate change scenario, an increase in the occurrence and intensity of ENSO events has been projected, linked to a deepening and flattening of the thermocline in the equatorial Pacific (Ashok
\& Yamagata, 2009; Yeh et al., 2009) so, in the long term, this could negatively affect the reproductive aspects of $L$. olivacea, in Playa Palmeras and possibly, in other beaches of the ETP. With the results obtained in the present study, the need for information on the distribution and population trends at broad geographic and temporal scales is evident; therefore, it is important to perpetuate and promote long-term capture and tagging monitoring such as that carried out in the PNNG, as they are important for the quantification of changes in nesting variables and provide the basis for making decisions in regarding the management and conservation of sea turtles, specially Olive Ridleys in the Pacific.

Ethical statement: authors declare that they all agree with this publication and made significant contributions; that there is no conflict of interest of any kind; and that we followed all pertinent ethical and legal procedures and requirements. All financial sources are fully and clearly stated in the acknowledgements section. A signed document has been filed in the journal archives.

\section{ACKNOWLEDGMENTS}

Valentina Cárdenas, Sergio Cañón and María del Mar Murillas for their contributions and accompaniment for 2018 season data collection. To Camilo Quesada, Alejandro Perlaza and Andrés Ocampo for their valuable contributions, comments and suggestions. To Hector Chirimia for its continued support to the marine turtle monitoring program of the PNNG. This research work was partially financed by Universidad del Valle (Vicerrectoría de Investigaciones, Grupo de Investigación en Ecología Animal) and Parque Nacional Natural Gorgona. A research permit from the Special Administrative Unit of the Sistema de Parques Nacionales Naturales (PIC 005-18) dated 13 April 2018 was granted to María Alejandra Ariza Gallego and Alan Giraldo. 


\section{RESUMEN}

Relación entre la temperatura superficial del mar y la anidación de la tortuga marina Golfina (Lepidochelys olivacea) (Testudines: Cheloniidae) en Isla Gorgona, Pacífico colombiano. Introducción: Lepidochelys olivacea es la tortuga marina más abundante del Pacífico colombiano y las condiciones oceanográficas en el Pacífico Oriental Tropical podrían tener un efecto en su comportamiento reproductivo. Objetivo: Evaluar la relación entre los aspectos reproductivos de L. olivacea anidantes en isla Gorgona y la temperatura superficial del mar a escala local y regional. Métodos: Se estableció la información promedio mensual de los atributos asociados con las hembras anidantes, nidos, huevos y neonatos utilizando los registros del monitoreo de anidación del Parque Natural Nacional Gorgona y se correlacionaron (correlación cruzada) con la temperatura superficial del mar de la Ensenada de Panamá y las aguas de Gorgona, y con la variabilidad en la temperatura de las regiones El Niño 1+2, El Niño 3, El Niño 3.4 y El Niño 4, sus anomalías térmicas y con los índices ONI y SOI. Las correlaciones significativas se incluyeron en modelos aditivos generalizados. Resultados: Las correlaciones inversas más altas, considerando que la máxima correlación es 1 se establecieron entre las visitas a la playa, el número de hembras anidantes, el número de nidos, el tamaño de las nidadas, los días de incubación y el éxito de eclosión y la región Niño 1+2 con un rezago de 12 meses, mientras que el diámetro y el peso de los huevos, el largo y ancho del caparazón y peso de los neonatos se correlacionaron con la anomalía de Niño 4 y los índices SOI y ONI. También se encontró que existe una tendencia no lineal a disminuir el número de hembras anidantes, número de nidos, tamaño de nidadas, diámetro y el peso de los huevos con anomalías regionales positivas. Conclusiones: Los atributos de anidación de L. olivacea en Gorgona se correlacionan principalmente con las variaciones en la temperatura superficial del mar regional, siendo bajos a temperaturas altas en el año anterior a la anidación (rezago de 12 meses).

Palabras clave: índices ENOS, anomalía térmica, Pacífico Oriental Tropical, Colombia, conservación.

\section{REFERENCES}

Alabia, I.D., Saitoh, S.I., Hirawake, T., Igarashi, H., Ishikawa, Y., Usui, N., ... Seito, M. (2016). Elucidating the potential squid habitat responses in the central North Pacific to the recent ENSO flavors. Hydrobiologia, 772(1), 215-227.

Alvarado, J., \& Murphy, T. (1999). Nesting Periodicity and Internesting Behavior. In K.L. Eckert, K.A. Bjorndal, F.A. Abreu-Grobois, \& M. Donnelly (Eds.), Research and Management Techniques for the Conservation of Sea Turtles (4 ${ }^{\text {th }}$ ed., pp. 115-118).
Blanchard, Pennsylvania USA: IUCN/SSC Marine Turtle Specialist Group.

Amador, J.A., Alfaro, E.J., Lizano, O.G., \& Magaña, V.O. (2006). Atmospheric forcing of the eastern tropical Pacific: A review. Progress in Oceanography, 69, 101-142.

Amorocho, D.F., Rodríguez-Zuluaga, J.A., Payán, L.F., Zapata, L.A., \& Rojas, P.A. (2015). Plan de manejo de las tortugas marinas del Parque Nacional Natural Gorgona. Planes de manejo Parque Nacional Natural Gorgona. Cali, Colombia: WWF-Colombia y Parques Nacionales Naturales.

Amorocho, D.F., Rubio, H., \& Díaz, W. (1992). Observaciones sobre el estado actual de las tortugas marinas en el Pacífico colombiano. In J.V. Rodriguez Mahecha \& H.S.P. Sánchez Páez (Eds.), Contribución al conocimiento de las tortugas marinas de Colombia (pp. 155-179). Bogotá D. C., Colombia: INDERENA.

Ashok, K., \& Yamagata, T. (2009). Climate change: The El Niño with a difference. Nature, 461(7263), 481-484.

Ballance, L.T., Pitman, R.L., \& Fiedler, P.C. (2006). Oceanographic influences on seabirds and cetaceans of the eastern tropical Pacific: A review. Progress in Oceanography, 69(2-4), 360-390. DOI: 10.1016/j. pocean.2006.03.013

Barreto-Sánchez, L.J. (2011). Diagnóstico del estado actual de las tortugas marinas en el Pacífico Colombiano. Colombia: Informe Nacional.

Barrientos-Muñoz, K.G., \& Ramírez-Gallego, C. (2008). Estado actual de Lepidochelys olivacea en El Valle, Pacifico Chocoano, Colombia. In S. Kelez, F. van Oordt, N. de Paz, \& K. Forsberg (Eds.), Libro de resúmenes II Simposio de tortugas marinas en el Pacifico Sur Oriental (pp. 17-21). Lima, Perú.

Barrientos-Muñoz, K.G., Ramírez-Gallego, C., \& Páez, V. (2014). Nesting ecology of the olive ridley sea turtle (Lepidochelys olivacea) (Cheloniidae) at El Valle beach, northern Pacific, Colombia. Acta Biológica Colombiana, 19(3), 437-445.

Barrientos-Muñoz, K.G., Ramírez-Gallego, C., \& Páez, V.P. (2015). Lepidochelys olivacea (Eschscholtz, 1829). In M.A. Morales-Betancourt, C.A. Lasso, V.P. Páez, \& B.C. Bock (Eds.), Libro Rojo de Reptiles de Colombia (2015) (pp. 161-165). Bogotá D. C., Colombia: Instituto de Investigación de Recursos Biológicos Alexander von Humboldt (IAvH).

Chaloupka, M., Kamezaki, N., \& Limpus, C. (2008). Is climate change affecting the population dynamics of the endangered Pacific loggerhead sea turtle? Journal of Experimental Marine Biology and Ecology, 356(12), 136-143.

Chambault, P., de Thoisy, B., Heerah, K., Conchon, A., Barrioz, S., Dos Reis, V., ... Chevallier, D. (2016). 
The influence of oceanographic features on the foraging behavior of the olive ridley sea turtle Lepidochelys olivacea along the Guiana coast. Progress in Oceanography, 142, 58-71.

Chavez, F.P., Strutton, P.C., Friederich, C.E., Feely, R.A., Feldman, G.C., Foley, D.G., \& Mcphaden, M.J. (1999). Biological and Chemical Response of the Equatorial Pacific Ocean to the 1997-98 El Niño. Science, 286(5447), 2126-2131.

Climate Prediction Center Internet Team. (2005). Climate Prediction Center - Southern Oscillation Index. Retrieved from https:/www.cpc.ncep.noaa.gov/products/analysis_monitoring/ensocycle/soi.shtml

Climate Prediction Center Internet Team. (2017). Monthly Atmospheric and Sea Surface Temperatures Indices. Retrieved from https://www.cpc.ncep.noaa.gov/ data/indices

Côté, I.M., \& Green, S.J. (2015). Potential effects of climate change on a marine invasion: The importance of current context. Current Zoology, 58(1), 1-8.

Del Monte-Luna, P., Guzmán-Hernández, V., Cuevas, E.A., Arreguín-Sánchez, F., \& Lluch-Belda, D. (2012). Effect of North Atlantic climate variability on hawksbill turtles in the Southern Gulf of Mexico. Journal of Experimental Marine Biology and Ecology, 412, 103-109.

Fiedler, P.C., \& Lavín, M.F. (2016). Oceanographic Conditions of the Eastern Tropical Pacific: Persistence and Loss in a Dynamic Environment. In P.W. Glynn, D.P. Manzello, \& I.C. Enochs (Eds.), Coral Reefs of the Eastern Tropical Pacific (1 ${ }^{\text {st }}$ ed., pp. 59-83). Dordrecht, Netherlands: Springer.

Giraldo, A., Rodríguez-Rubio, E., \& Zapata, F. (2008). Condiciones oceanográficas en isla Gorgona, Pacífico oriental tropical de Colombia. Latin American Journal of Aquatic Research, 36(1), 121-128.

Giraldo, A., Valencia, B., Acevedo, J.D., \& Rivera, M. (2012). Columna de agua en el Parque Nacional Natural Gorgona. In A. Giraldo \& B. Valencia (Eds.), Isla Gorgona: paraíso de biodiversidad y ciencia (pp. 27-44). Cali, Colombia: Programa Editorial Universidad del Valle.

Gunderson, A.R., Armstrong, E.J., \& Stillman, J.H. (2016). Multiple stressors in a changing world: the need for an improved perspective on physiological responses to the dynamic marine environment. Annual Review of Marine Science, 8(1), 357-378.

Hallett, T.B., Coulson, T., Pilkington, J.G., Clutton-Brock, T.H., Pemberton, J.M., \& Grenfell, B.T. (2004). Why large-scale climate indices seem to predict ecological processes better than local weather. Nature, $430,71-75$
Hamann, M., Limpus, C.J., \& Whittier, J.M. (2002). Patterns of lipid storage and mobilisation in the female green sea turtle (Chelonia mydas). Journal of Comparative Physiology B: Biochemical, Systemic, and Environmental Physiology, 172(6), 485-493.

Hinestroza, L.M., \& Páez, V.P. (2001). Anidación y manejo de la tortuga golfina (Lepidochelys olivacea) en la playa La Cuevita, Bahía Solano, Chocó, Colombia. Cuadernos de Herpetología, 14(2), 131-144.

IUCN. (2019). The IUCN red list of threatened species. Retrieved from http://www.iucnredlist.org/search

Kim, W., Yeh, S.W., Kim, J.H., Kug, J.S., \& Kwon, M. (2011). The unique 2009-2010 El Niño event: A fast phase transition of warm pool El Niño to la Niña. Geophysical Research Letters, 38(15), 1-5.

Kozak, E.R., Franco-Gordo, C., Suárez-Morales, E., \& Palomares-García, R. (2014). Seasonal and interannual variability of the calanoid copepod community structure in shelf waters of the Eastern Tropical Pacific. Marine Ecology Progress Series, 507, 95-110.

Lavín, M.F., Fiedler, P.C., Amador, J.A., Ballance, L.T., Färber-Lorda, J., \& Mestas-Nuñez, A.M. (2006). A review of eastern tropical Pacific oceanography: Summary. Progress in Oceanography, 69, 391-398.

León-Chávez, C.A., Beier, E., Sánchez-Velasco, L., Barton, E.D., \& Godínez, V.M. (2015). Role of circulation scales and water mass distributions on larval fish habitats in the Eastern Tropical Pacific off Mexico. Journal of Geophysical Research: Oceans, 120(6), 3987-4002.

Martinez, L.M., \& Páez, V.P. (2000). Ecología de anidación de la tortuga golfina (Lepidochelys olivacea) en la playa de La Cuevita, costa pacífica Chocoana, Colombia, en 1998. Actualidades Biológicas, 22(73), 131-143.

Masotti, I., Moulin, C., Alvain, S., Bopp, L., Tagliabue, A., \& Antoine, D. (2011). Large-scale shifts in phytoplankton groups in the Equatorial Pacific during ENSO cycles. Biogeosciences, 8(3), 539-550.

Mazaris, A.D., Kallimanis, A.S., Sgardelis, S.P., \& Pantis, J.D. (2008). Do long-term changes in sea surface temperature at the breeding areas affect the breeding dates and reproduction performance of Mediterranean loggerhead turtles? Implications for climate change. Journal of Experimental Marine Biology and Ecology, 367(2), 219-226.

Mazaris, A.D., Kornaraki, E., Matsinos, Y.G., \& Margaritoulis, D. (2004). Modeling the effect of sea surface temperature on sea turtle nesting activities by investigating seasonal trends. Natural Resource Modeling, 17(4), 445-465.

McCormick, C.C. (1996). Contribución al conocimiento de la biología y ecología de las tortugas marinas 
en la isla Gorgona (Tesis de grado). Universidad del Valle, Colombia.

Miller, D.J. (1997). Reproduction in sea turtles. In P.L. Lutz \& J.A. Musick (Eds.), The biology of sea turtles (pp. 51-83). Boca Ratton, USA: CRC Press.

Montealegre, J.E. (2007). Modelo institucional del IDEAM sobre el efecto climático de los fenómenos El Niño y La Niña en Colombia. Bogotá D.C., Colombia: Instituto de Hidrología, Meteorología y Estudios Ambientales, IDEAM.

O’Connor, M.I., Bruno, J.F., Gaines, S.D., Halpern, B.S., Lester, S.E., Kinlan, B.P., \& Weiss, J.M. (2007). Temperature control of larval dispersal and the implications for marine ecology, evolution, and conservation. Proceedings of the National Academy of Sciences, 104(4), 1266-1271.

Ocean Biology Processing Group. (2015). MODIS Aqua Level 3 SST Thermal IR Monthly $4 \mathrm{~km}$ Daytime v2014.0. Ver.2014.0. CA, USA: PO.DAAC. Retrieved from https://podaac.jpl.nasa.gov/dataset/MODIS AQUA_L3_SST_THERMAL_MONTHLY_4KM DAYTIME $\overline{\text { V2014.0 }}$

Paine, R.T., Tegner, M.J., \& Johnson, E.A. (1998). Compounded Perturbations Yield Ecological Surprises. Ecosystems, 1(6), 535-545.

Paredes, C., Cardoso, F., \& Tarazona, J. (2004). Distribución temporal de moluscos y crustáceos tropicales en la Provincia Peruana y su relación con los eventos El Niño. Revista Peruana de Biología, 11(2), 213-218.

Pavía, A., Rodríguez-Zuluaga, J.A., \& Amorocho, D.F. (2006). Monitoreo de la biología reproductiva de la tortuga caguama del Pacífico (Lepidochelys olivacea) en el Parque Nacional Natural GorgonaPacífico de Colombia. Informe final presentado a National Fish and Wildlife Foundation (NFWF). Cali, Colombia.

Payán-Perea, L.F., Zorrilla-Arroyave, M.X., \& ChirimíaGonzáles, H. (2016). Monitoreo del Programa de Conservación de tortugas marinas en el Parque Nacional Natural Gorgona. In L.J. Barreto Sánchez (Ed.), Conservación de tortugas Marinas en Colombia (Vol. 1, pp. 145-122). Bogotá, Colombia: Fundación Conservación Ambiente Colombia.

Plotkin, P.T. (2010). Nomadic behaviour of the highly migratory olive ridley sea turtle Lepidochelys olivacea in the eastern tropical Pacific Ocean. Endangered Species Research, 13(1), 33-40.

Polidoro, B.A., Brooks, T., Carpenter, K.E., Edgar, G.J., Henderson, S., Sanciangco, J., \& Robertson, D.R. (2012). Patterns of extinction risk and threat for marine vertebrates and habitat-forming species in the Tropical Eastern Pacific. Marine Ecology Progress Series, 448, 93-104.

Pritchard, P.C.H., \& Plotkin, P.T. (1995). Olive Ridley sea turtle. In P.T. Plotkin (Ed.), National Marine
Fisheries Service and U.S. Fish and Wildlife Service Status reviews of sea turtles listed under the Endangered Species Act of 1973 (pp. 123-139). Maryland, USA: Silver Spring.

Saba, V.S., Santidrián-Tomillo, P., Reina, R.D., Spotila, J.R., Musick, J.A., Evans, D.A., \& Paladino, F.V. (2007). The effect of the El Niño Southern Oscillation on the reproductive frequency of eastern Pacific leatherback turtles. Journal of Applied Ecology, 44(2), 395-404.

Saba, V.S., Shillinger, G.L., Swithenbank, A.M., Block, B.A., Spotila, J.R., Musick, J.A., \& Paladino, F.V. (2008). An oceanographic context for the foraging ecology of eastern Pacific leatherback turtles: Consequences of ENSO. Deep-Sea Research Part I: Oceanographic Research Papers, 55(5), 646-660.

Seminoff, J.A., Alfaro-Shigueto, J., Amorocho, D.F., Arauz-Vargas, R., Baquero Gallegos, A., ChacónChaverri, D., ... Wallace, B.P. (2012). Biology and conservation of sea turtles in the eastern Pacific Ocean. In J.A. Seminoff, B.P. Wallace, \& P.C.H. Pritchard (Eds.), Sea Turtles of the Eastern Pacific: Advances in Research and Conservation ( $2^{\text {nd }}$ ed., pp. 11-38). Arizona, USA: University of Arizona Press.

Solow, A.R., Bjorndal, K.A., \& Bolten, A.B. (2002). Annual variation in nesting numbers of marine turtles: the effect of sea surface temperature on remigration intervals. Ecology Letters, 5, 742-746.

StatSoft, I. (2004). STATISTICA (data analysis software system). Retrieved from www.statsoft.com

Varo-Cruz, N., Monzón-Argüello, C., Carrillo, M., Calabuig, P., \& Liriz-Loza, A. (2015). Tortuga oliváceaLepidochelys olivacea (Eschscholtz, 1829). In A. Salvador \& A. Marco (Eds.), Enciclopedia Virtual de los Vertebrados Españoles (pp.1-28). Madrid, España: Museo Nacional de Ciencias Naturales.

Wallace, B.P., \& Jones, T.T. (2008). What makes marine turtles go: A review of metabolic rates and their consequences. Journal of Experimental Marine Biology and Ecology, 356(1-2), 8-24.

Wallace, B.P., Kilham, S.S., Paladino, F.V., \& Spotila, J.R. (2006). Energy budget calculations indicate resource limitation in Eastern Pacific leatherback turtles. Marine Ecology Progress Series, 318, 263-270.

Wang, C., \& Fiedler, P.C. (2006). ENSO variability and the eastern tropical Pacific: A review. Progress in Oceanography, 69, 239-266.

Yeh, S.W., Kug, J.S., Dewitte, B., Kwon, M.H., Kirtman, B.P., \& Jin, F.F. (2009). El Niño in a changing climate. Nature, 461(7263), 511-514. 